\title{
SYMPOSIUM ON SOFT AND HARD LAW ON BUSINESS AND HUMAN RIGHTS
}

\section{HARD AND SOFT LAW PREFERENCES IN BUSINESS AND HUMAN RIGHTS}

\author{
Kishanthi Parella*
}

States and non-state actors, such as business organizations and NGOs, have varying preferences among regulatory options in business and human rights. Some actors prefer soft law governance while others advocate for legally binding solutions at the national and international levels. In this essay, I explore some of the factors that may explain why state and non-state actors hold these diverse preferences. I conclude that while some of these preferences may be attributable to the unique advantages of soft law or hard law, other preferences likely depend on the effects produced by the interaction of both types of law within the broader regulatory landscape.

\section{Explaining Preferences: Soft Law Versus Hard Law}

"Hard law" and "soft law" are often distinguished by reference to three dimensions: legal obligation, delegation, and precision. ${ }^{1}$ The proposed Business and Human Rights (BHR) Treaty offers a hard law approach because it would impose legally binding and precise obligations on state parties with associated institutional arrangements. National legislation addressing BHR also represents a hard law development. "Soft law" refers to institutions that are weakened along one or more of these three dimensions. ${ }^{2}$ A number of factors may lead state and non-state actors to prefer either hard law or soft law. Some of these factors have traditionally explained state preferences, while others are unique to non-state actors, especially business organizations.

\section{Uncertainty \& Information Gathering}

Both state actors and business organizations may prefer soft law when they encounter uncertainty regarding coordination with others. This uncertainty results from a lack of information regarding how two different audiences may respond to a new institution: (a) peer audiences, and (b) constituent audiences. ${ }^{3}$ Either actor may encounter significant costs if it proceeds ahead in the face of such uncertainty.

States may prefer soft law when they do not know whether other states will keep their own commitments. A state that keeps its commitments while its peers do not may sustain significant political and economic costs. For example, the BHR Treaty requires that state parties implement domestic legislation requiring due diligence, as well as

* Associate Professor of Law, Washington and Lee University School of Law

${ }^{1}$ Kenneth W. Abbott \& Duncan Snidal, Hard and Soft Law in International Governance, 54 InT'L Org. 421 (2000).

${ }^{2} I d$. at 422 .

${ }^{3}$ Kenneth A. Abbott \& Duncan Snidal, Pathways to International Cooperation, in The Impact of International Law on International Cooperation: Theoretical Perspectives 69-70 (Eyal Benvenisti \& Moshe Hirsch eds., 2004).

(C) Kishanthi Parella 2020. This is an Open Access article, distributed under the terms of the Creative Commons Attribution licence (http://creativecommons.org/licenses/by/4.0/), which permits unrestricted re-use, distribution, and reproduction in any medium, provided the original work is properly cited. 
provisions for legal liability. ${ }^{4}$ States may fear that implementing these laws when their peers do not will lead to corporate flight as corporations relocate to another state that declines to pass such laws. They will therefore prefer soft law approaches that provide them with flexibility and adaptability to respond to these potential costs until peer states are willing to make similar credible commitments through hard law. Second, state actors may want to know how strongly domestic constituents may resist or favor the institution because those reactions determine the political cost of a treaty commitment.

Business organizations may similarly prefer soft law approaches in situations of uncertainty. They may not know whether their peers intend to commit to such guidelines; moving ahead while peers do not may impose costs relative to their peers that have subsequent competitive effects. Businesses may also lack information regarding how their own stakeholders, such as employees, shareholders, and consumers, may respond to these guidelines. Soft law allows business organizations time to experiment with these approaches while gauging how these groups react. Soft law also allows these organizations to exit at lower cost if the reactions are not beneficial to the organization.

\section{Sequencing Between Soft and Hard Law}

Sequencing soft and hard law offers advantages to a wide variety of actors. Starting with soft law guidelines allows business organizations time to experiment with best practices. These best practices can subsequently inform the hard law requirements that follow in sequence, thereby enabling more precise guidance in hard law's substantive content because of the time that business organizations have for experimentation. These advantages would interest a broad spectrum of actors, including NGOs, who may prefer more precise guidance regarding corporate conduct because the greater detail provides NGOs with benchmarks against which they can evaluate compliance and shame actors who fail to comply. ${ }^{5}$

Sequencing also potentially benefits business organizations in ways different from its appeal to NGOs. First, it allows business organizations an opportunity to learn new practices through soft law and to adapt these practices within company operations before a state in which they operate mandates that they do so. This may reduce the regulatory burden on companies because they have already started the process of compliance with these norms. This reduced regulatory burden may, in turn, decrease the political costs that companies may impose on state actors who commit to the treaty (thereby also benefiting state actors). Second, the experimentation time allows business organizations an opportunity to determine what changes are more or less costly so the resulting best practices may simply be the cheapest practices for them.

\section{Leveling the Playing Field}

Business organizations may prefer an international agreement when it has the potential to level the field among competitors. Imagine three different scenarios that lead to different competitive consequences for businesses depending on the extent that each business is regulated within the same jurisdiction. The differences in the extent of regulation can result in three different types of "field dynamics": open field (no hard law regulation), uneven field (some hard law regulation), and level field (towards uniform hard law regulation across all business actors).

\footnotetext{
${ }^{4}$ UN OEIGWG Chairmanship, Revised Draft, Legally Binding Instrument to Regulate, in International Human Rights Law, the Activities of Transnational Corporations and Other Business Enterprises (July 16, 2019), [hereinafter Revised Draft LBI].

${ }^{5}$ See Thomas Risse \& Kathryn Sikkink, The Socialization of International Human Rights Norms into Domestic Practices: An Introduction, in THE Power of Human Rights: International Norms \& Domestic Change 11 (Thomas Risse et al. eds., 1999).
} 


\begin{tabular}{|c|c|c|c|}
\hline & Scenario 1 & Scenario 2 & Scenario 3 \\
\hline Soft Law/Hard Law Composition & $\begin{array}{l}\text { - Only Soft Law } \\
\text { - No national hard law } \\
\text { - No international } \\
\text { hard law }\end{array}$ & $\begin{array}{l}\text { - Some soft law } \\
\text { - Some countries adopt hard law } \\
\text { while others do not } \\
\text { - No international hard law }\end{array}$ & $\begin{array}{l}\text { - } \text { Some soft law } \\
\text { - Many countries adopt } \\
\text { - Iniform hard law } \\
\text { International hard law }\end{array}$ \\
\hline Field Dynamics & Open Field & Uneven Field & Level Field \\
\hline $\begin{array}{l}\text { Corporate Preferences } \\
\text { (Transnational Actors) }\end{array}$ & 1 & 3 & 2 \\
\hline $\begin{array}{l}\text { Corporate Preferences } \\
\text { (Purely Domestic Actors) }\end{array}$ & 1 & 2 & 3 \\
\hline
\end{tabular}

In Scenario 1, there are no hard law approaches (either international or domestic). Some business organizations voluntarily abide by soft law but realize that, in doing so, they incur costs that their peers do not; as such, they may prefer soft law so that they can exit the institution more easily if these costs prove too high.

In Scenario 2, some countries (e.g., Country A) implement BHR legislation while others (e.g., Country B) do not. These laws level the playing field among competitors within Country A. Business organizations within Country A that were considering adopting enhanced BHR practices, perhaps through a soft law institution, may support national legislation in Country A because they can now act on their preferences without raising their own costs relative to their peers. ${ }^{6}$ Foreign competitors from Country B typically need to comply with Country A's laws when they compete in Country A's markets. As such, a business organization from Country A is on a level playing field with both domestic and foreign competitors within Country A.

The level playing field vanishes if businesses compete in Country B, which does not have BHR legislation. A business organization from Country A may still need to comply with the national legislation of Country A even if operating in Country B. But its competitors in Country B may not be similarly constrained because neither Country $\mathrm{B}$ nor a third jurisdiction regulates their BHR activities. Therefore, the business organization from Country A will operate at a higher cost in Country B compared to its rivals.

A business organization in this position may therefore prefer a more uniform standard (Scenario 3) across all countries that helps to level the playing field among competitors in all the markets in which it wants to participate. While national hard law may still vary as countries adapt the treaty's requirements to their circumstances, businesses may still prefer this approach if it results in a less uneven field as compared to Scenario 2. Scenario 3 is not necessarily the preferred choice among business organizations; Scenario 1 may be the optimal situation. But once some hard law is introduced, business organizations may prefer Scenario 3 and consider Scenario 2 the worst outcome. However, the preference for Scenario 3 also depends on the extent of the global footprint that a business organization possesses. Businesses from regulated countries operating in unregulated ones may prefer Scenario 3. However, businesses operating exclusively in Country A or Country B may not share the same preferences.

\footnotetext{
${ }^{6}$ See Nicole Deitelhoff \& Klaus Dieter Wolf, Business and Human Rights: How Corporate Norm Violators Become Norm Entrepreneurs, in THE Persistent Power of Human Rights 227 (Thomas Risse et al. eds., 2013).
} 


\section{Signaling \& Brand}

One reason that businesses may prefer voluntary commitment under soft law is because it provides them with reputational benefits that may not accompany compliance with hard law. By undertaking voluntary action that is not legally required, businesses signal attributes about themselves to key stakeholders who value businesses going above and beyond. With a soft law baseline, compliance yields reputational benefits. Once the baseline hardens, compliance is expected because it is required. It may not yield the same kinds of reputational benefits because compliance does not signal organizational attributes except that the business is law-abiding. However, a business may incur reputational sanctions for non-compliance that may not accompany non-compliance with soft law. Hard law also standardizes practices across all businesses. This may impact businesses that build their brand around voluntary practices that distinguish them in the marketplace. Hard law may dilute this differentiation if other businesses are going to abide by similar practices.

\section{Interactive Effects: Preferences Produced Through Interaction Between Hard and Soft Law}

Actor preferences for a particular BHR approach might depend on how hard and soft law interact and produce effects through that interaction, rather than on either approach in isolation. This interaction may involve conflict or complementarity.

\section{Complexity as a Good}

Some actors may desire a crowded regulatory landscape characterized by complexity. ${ }^{7}$ Complexity can preserve an actor's power in at least two ways. First, multiple options allow an actor to threaten exit in favor of an alternative regulatory framework (or to create a new one) if the actor's preferences are not honored. ${ }^{8}$ Second, more regulatory options reduce accountability because they make it more challenging to ascertain the relevant standards. ${ }^{9}$ Even if clear, they may vary. This ambiguity allows a state to "regime-shop" to pick the regulatory option that asks the least of it and therefore always remain in compliance with at least one regulatory framework in the policy area. ${ }^{10}$

\section{Exporting Regulatory Preferences: Treaties as Products}

BHR norms are increasingly "domesticated" even in the absence of an international agreement. Domestication allows states to apply these norms to private actors, such as business organizations, and well-established courts to adjudicate and enforce them; these advantages are particularly important in BHR because many victims otherwise lack options for holding business accountable.

Several states have adopted national legislation that imposes heightened disclosure requirements on companies concerning their human rights practices in supply chains, including the United Kingdom, Australia, and New South Wales. ${ }^{11}$ Additional legislation is pending or proposed in the Netherlands, Canada, and the United

\footnotetext{
7 See Gregory Shaffer \& Mark A. Pollack, Hard v. Soft Law: Alternatives, Complements, and Antagonists in International Governance, 94 MinN. L. Rev. 706, 745-48 (2009).

${ }^{8} \underline{I d}$.

9 See Karen J. Alter \& Kal Raustiala, The Rise of International Regime Complexity, 14 Annual Rev. L. \& Soc. 329, 339 (2018).

${ }^{10} I d$.

11 See, e.g., Modern Slavery Act 2015, 2015 c.30 (UK).
} 
States. ${ }^{12}$ Additionally, France introduced both a binding due diligence obligation and liability for those companies that fail to do so. ${ }^{13}$ These examples illustrate how some of the human rights due diligence norms from the Guiding Principles are making their way into domestic legislation directly even in the absence of an international agreement.

But these domestic laws are not the same. The French approach sets mandatory due diligence requirements and provisions for legal liability; in contrast, many other countries opt for mandatory reporting that requires disclosure of the due diligence steps taken (or not). While both types of regulation may share similar aims, they adopt different levers to incentivize companies to get there: the first depends directly on mandatory legal requirements while the second relies on a combination of reporting requirements and reputational sanctions to pressure companies to improve their practices. This latter approach is becoming a popular template for many countries contemplating BHR regulation. However, some critics worry that reputational sanctions are insufficient to change practices and may prefer mandatory due diligence requirements. ${ }^{14}$

These different approaches highlight the potential for conflict when actors agree that something should be done but disagree on the approach to take because the specific rules chosen can impose different costs and benefits on different actors. In the BHR context, an international agreement may allow some actors to export their preferences $^{15}$ for domestic regulation to an audience of undecided states that may contemplate some form of BHR regulation but have not implemented a particular approach. Advocates for mandatory due diligence requirements may view the BHR Treaty, focusing on prevention and legal liability, as a means to export their preferences for this regulatory approach to reach undecided states. In this scenario, an international hard law tool offers a way for some actors to export their preferences and preclude a rival regulatory approach, even one that is embodied in hard law. However, these dynamics depend on the treaty entering into force; these preferences are therefore dependent on the "outcome effects" of the treaty-making process.

\section{Reputational Effects \& Institutional Pluralism: Treaties as Process}

The BHR treaty-making process may also encourage business actors to adhere to soft law addressing BHR through the publicity and reputational effects the treaty-making process generates. These are the "process effects" that accompany treaty-making and can result even if the prospective treaty does not enter into force. Advocates of a treaty desire the effects that the treaty making process may produce and the consequences of those effects on the alternative institutions in this field, such as the UNGPs. For example, the introduction of the BHR treaty-making process may change business actors' compliance with the UNGPs through at least two different types of interactive effects. First, the BHR treaty process shines a light on the underlying issues and may elevate the issues through annual meetings, drafts of text, invitations for commentaries, and additional forms of engagement with a variety of stakeholders.

Second, proposals for hard law terms may reflect perceived defects in the soft law approach. These drafts draw attention to the current inadequacies of the status quo, placing issues on the treaty agenda (and within draft text), and shaming actors for their lack of performance on these issues. This shaming leads to publicity that can (a)

12 See Michael R. Littenberg \& Nellie V. Binder, Corporate Social Responsibility Disclosure and Compliance: An Overview of Selected Legislation, Guidance and Voluntary Initiatives, (PLI Institute on Securities Regulation, Oct. 2019).

13 See, e.g., European Coal. for Corp. Justice, French Corporate Duty of Vigilance Law: Frequently Asked Questions 2 (Feb. 23, 2017).

14 See, e.g., Justine Nolan, Hardening Soft Law: Are the Emerging Corporate Social Disclosure Laws Capable of Generating Substantive Compliance with Human Rights?, 15 BraziLian J. Int'L Law 65, 68-70 (2018); Sandra Cossart et al., The French Law on Duty of Care: A Historic Step Towards Making Globalization Work For All, 2 Bus. Human RTs. J. 317, 319-320 (2017).

${ }^{15}$ Barbara Koremenos \& Mihwa Hong, The Rational Design of Human Rights Agreements 5 (APSA 2010 Annual Meeting Paper, 2011). 
enable NGOs to pressure recalcitrant companies, ${ }^{16}$ and (b) improve compliance with soft law tools as companies demonstrate the effectiveness of soft law approaches in order to resist hard law alternatives. ${ }^{17}$ In these ways, hard law (and even law in process) can complement the effectiveness of soft law. ${ }^{18}$

\section{Conclusion}

The regulatory landscape for BHR is growing increasingly complex as more countries introduce new laws and business actors evaluate soft law options. States, business organizations, NGOs, and other actors differ in which of these options they may prefer. These preferences might not depend as much on the advantages of soft law or hard law independently but on how each choice fits within the broader regulatory environment and how the interaction between the two produces effects. For example, business actors may prefer a hard law approach depending on the extent to which they are similarly regulated as their market rivals. NGOs and businesses may prefer soft law as a prelude to a hard law approach, and states and businesses may turn to a treaty to supplant alternative hard law options. In these ways, preferences remain dynamic and responsive to how the regulatory landscape for BHR develops.

${ }^{16}$ Risse \& Sikkink, supra note 10 at 11-19.

${ }^{17}$ Revised Draft LBI, supra note 4, at 3; see also David G. Victor et al., Introduction and Overview, in The Implementation AND EFFECTIVENEsS of International Environmental Commitments 23 (David G. Victor et al. eds., 1998).

18 Kishanthi Parella, Treaty Penumbras, 38 U. PA. J. INT'L L. 275, 292-303 (2017). 